\title{
ROLE OF SOCIAL MEDIA IN PROMOTING TOURISM IN PAKISTAN
}

\author{
Shaista Aftab* \\ Muhammad Moiz Khan ${ }^{* *}$
}

\begin{abstract}
Tourism has emerged as the fastest growing industry and source of foreign exchange all across the world. Many countries owe major part of their annual earning and wealth to tourism. Pakistan is amongst the best tourism destination in the world. The main attractions for international travelers are usually, mountains, snow, desserts, beaches, plains, rivers, forests, cliffs, scenic beauty, historical places and cultural diversity. Pakistan is blessed with all of the said attractions. Up until now Pakistan had faced two major impediments towards becoming the top tourist destination, first it was not properly showcased in-front of the world and secondly in the recent past the security conditions were not suitable for international visitors. Today, it is high time for the Pakistan to become the top priority for tourists from all across the world. In this regard Social Media can play the best role possible. Various social media platforms are full of pictures and stories of people describing their experiences about the places they had been to. Secondly the governmental organizations also launch various social media office profile to show case the destinations. In this research the need of social media for the promotion of tourism in Pakistan has been focused.
\end{abstract}

Keywords: Tourism, social media, internet, tourism information, planning, tourist destination

\section{Introduction}

Pakistan is emerging as one of the most potential tourist destinations of the world according to World Travel and Tourism Council. According to Travel and Tourism competitiveness Report 2017, released by World Economic Forum the total contribution of tourism in 2015 to the GDP of Pakistan was 328.3 million U.S \$, raised to a total of 7.6 billion U.S \$ in 2016, this accounted for $2.8 \%$ of total GDP and is expected to grow an average of $5.9 \%$ annually, thus, provided a total of 3,894,000 jobs in 2017. According to Forb's Magazine (2018) Pakistan has attained a prominent position among world's ten most potential tourist destinations. While tourism industry is growing at a significant growth rate, social media is serving as a most efficient publicity and marketing tool for tourism industry. Now a day social media is a rising trend and a huge part of people's everyday lives and at the same time getting more and more momentum in tourism industry like all the other industries in world. Like other industries, tourism industry is also taking advantage of social media platforms as the industry has mainly relied on the reputation of destination, opinion of the tourists, spread of information and positive word of mouth advertisement. For the last few years there are observed remarkable results in

\footnotetext{
* Shaista Aftab, Student of M.Phil. Pakistan Study Centre, University of Karachi

${ }^{* *}$ Muhammad Moiz Khan, Ph.D., Assistant Professor, Department of History, University of Karachi
} 
increased rate of visits along with the tourist's satisfaction after the introduction of social media into the marketing strategy for tourism development of Pakistan. So due to integration of social media as a cost efficient and effective tool for tourism marketing, tourism industry in depending more and more on social media platforms.

The framework of the research revolves around the role of social media in promoting tourism in Pakistan. The article concentrates on the usage of social media as a source of information regarding destination, a tool for planning and conducting tours and a way to share the experiences of the travelers to inspire the potential tourists.

\section{Research Objectives}

To analyze the role of social media in promoting tourism in Pakistan

\section{Research Questions}

1. Is social media an important source of tourism related information for tourists in Pakistan?

2. How do social media facilitate the tourists in planning their trip?

3. How social media platforms are used by travelers to inspire the potential tourists while conducting their trips?

\section{Literature Review}

Word social media means the ways of communication and interactions among people, where they communicate, create, share and exchange information, experiences and ideas in virtual platforms, communities and networks. Platforms like Facebook, twitter, Instagram, WhatsApp etc. are gaining more and more importance for personal and business uses. Like other industries social media has made an enormous effect on the tourism industry as well. Users get engage with social networking sites in order to be updated while planning for their tours and share their personal experiences regarding their tour, accommodation, transportation, customer services etc. while considering social media as a customer service channel it is simply impossible to ignore it. ${ }^{1}$

Users are now facilitated through these platforms to share their travel experiences with a larger and wider audience than ever before. Social media applications are given a new shape to tourist destination promotion. Besides this social media platforms are playing a significant role in tourism promotion and tourism service providers to focus on their best services through feedback they get through their clients and other users on social media. ${ }^{2}$

\footnotetext{
${ }^{1}$ Tafveez Mir, "Role of social media in tourism: a literature review." International Journal for Research in Applied Science and Engineering Technology 5, no. 11 (2017): 633-635, 633

${ }^{2}$ Benxiang Zeng, and Rolf Gerritsen. "What do we know about social media in tourism? A review", Tourism Management Perspectives 10 (2014): 27-36, 28
} 
In $21^{\text {st }}$ century the promotion of tourism has entered into a new era where "WOM" (word of mouth) publicity is replaced by online publicity and social media has emerged as most powerful tool to promote tourism in every country, region and destination.

\section{Tourism}

In 1991 the United Nations World Tourism Organization defined tourism as "travelling to and staying in places outside their usual environment for not more than one consecutive year for leisure, business and other purposes". ${ }^{3}$ Individuals become tourists when they leave their surroundings and travel to another place. So whatever they do during their visit would be enlisted as tourism activity. ${ }^{4}$

Travel and tourism has gained the position of a leading industry in the world during the past decades and proved to be a diverse sector. Putting aside the occasional shocks, this industry has shown a virtually uninterrupted growth. ${ }^{5}$ According to UNWTO tourism industry has shown a tremendous increase of $7 \%$ in 2017 globally and a rise of $4 \%$ more is expected in 2018.

The growth of multiple subsectors like transportation, hoteling, restaurants, shops, travel guides, tourist operators etc. is also attached to this industry. The growth of all of these sectors plays a significant role in enhancing economic activities and creating more chances of employment in the tourist areas.

\section{Tourism Industry in Pakistan}

According to the report, 1.75 million tourist visited Pakistan in 2017 alone. Statistics from the Pakistan Tourism Development Cooperation (PTDC) shows the 30\% travelers were domestic. Due to improved security situations tourism has increased by $300 \%$ over the past few years. ${ }^{6}$ According to The World Travel and Tourism Council (WTTC), the total contribution of tourism in the GDP of Pakistan showed a growth of 5.8\% in the year 2018 while talking about it's contribution to employment a rise of $2.6 \%$ was shown. WTTC is expecting the rise in this amount to $\$ 36.1$ billion within a decade. Along with this marvelous increase in annual tourism there is a significant increase in business activity around the country as well. ${ }^{7}$ The government of Pakistan is putting efforts through PTDC to improve tourism industry in Pakistan. Besides efforts made by PTDC a lot of the credit for this rapid increase in tourism goes to promotion of different tourist spots through the internet and social media platforms.

\section{Social Media}

Social media can be defined as websites and applications that enables users to create and share content and to participate in social networking. These platforms are interactive

\footnotetext{
${ }^{3}$ Mark Anthony Camilleri, “The Tourism Industry: An Overview.” In Travel Marketing, Tourism Economics and the Airline Product, pp. 3-27, 2. Springer, Cham, 2018.

${ }^{4}$ Ibid., p.2

${ }^{5}$ Rana Aftab-ur-Rehman, Promotion of tourism in Pakistan (Islamabad: Pildat, 2015), p.9

${ }^{6}$ Jamal Farrukh, "Recent Situation of Tourism in Pakistan" a Perspective of PTDC.(DAWN, April 15, 2018)

7 "Travel and Tourism Economic Impact 2018 Pakistan". (World Travel and Tourism Council.2018), p.9
} 
computer-mediated technologies that enables the creation and sharing of information, ideas, Interests etc. via virtual communities. According to another definition social media is the collection of online communication channels dedicated to community-based input, interaction, content sharing and collaboration. ${ }^{8}$ There are different types of social media channels and platforms with distinguishable features.

\section{Types of Social Platforms}

According to universal McCann 2008 the key social platforms are:

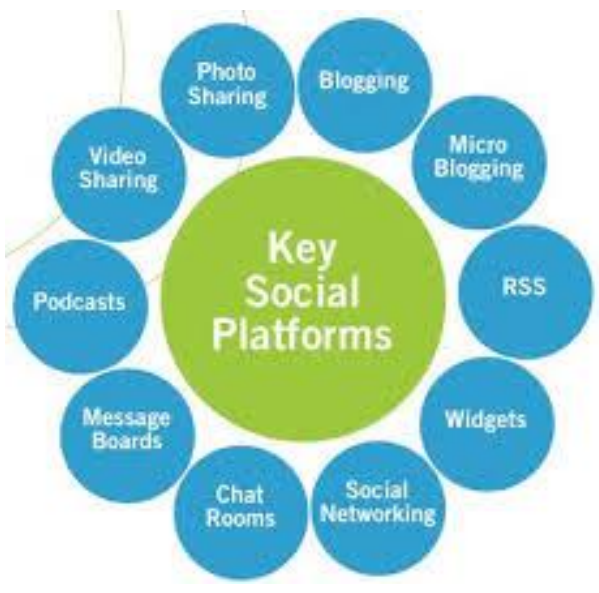

FIGURE 1: Key social platforms (Universal McCann 2008, date of retrieval 18.10.2011\}

Some currently in-use famous social networks are:

- WhatsApp

- Instagram

- Twitter

- Facebook

- YouTube

- Flicker etc.

Talking about tourism in under developed countries like Pakistan there are many dimensions including education, awareness, social interaction, economic contribution and social change on the conditions of the local community involvement. Online communities of people sharing common interests and activities are known as social networks. Social communities facilitate a user with a variety of interaction options, from simple chat to video conferencing and from messaging through email to blogging, vlogging and group discussions. These social networks also offer the facility of making groups containing categorized relationships (e.g former college mates), ways to communicate with friends or advertising system for carrying out economic activities. Popular spaces combine

\footnotetext{
${ }^{8}$ Jamal Farrukh, Op.cit.
} 
different functions of this type. ${ }^{9}$ Internet and mobile based online communities are generally associated by users generated content, web 2.0, social networking sites and virtual worlds etc. These sites serve as the additional source of information for travelers in addition to the conventional sources of travel related information. ${ }^{10}$ On most popular sites like Facebook, Twitter, Instagram and You Tube, millions of people per hour use to share their views via pictures, messaging, video sharing and other online methods. If we talk about Facebook it seems that about 1.6 billion people per month join it, and of course sending and uploading millions of data content per hour. These new technologies facilitate the user customization, enabling to personalize their tools, internet portals or discussion board. ${ }^{11}$

\section{Social Media and Tourism Industry}

The distinction between traditional media and social media has to be established in order to understand how social media functions and what social media should be used for. The nature of social media is communicative and it cannot be viewed as traditional marketing communication channel. ${ }^{12}$

In $21^{\text {st }}$ century the promotion of tourism has entered into a new era where "WOM" (word of mouth) publicity is replaced by online publicity and social media has emerged as most powerful tool to promote tourism in every country, region and destination. ${ }^{13}$ Social media has changed the landscape completely. Today most of the domestic and foreign travelers determine their travel plans based on social media shares and reviews. Emergence of social media has disrupted the traditional customer service model. From information search to decision making behavior, social media plays a significant role in many aspects of tourism. Social media also plays a significant role in tourism promotion and helps the tourism service providers in focusing on the best practices through feedback they get from tourists and public through social media. Social media is considered to be an important strategy in order to market tourism products.

\section{Social Media in Tourism Marketing}

Social interaction of the people through internet has opened new horizons of opportunities. Generally travelers use social media and online communities in order to seek information from users regarding their potential trip or to generate the content relating to their experiences of tour, in the form of comment, reviews and pictures. ${ }^{14}$

\footnotetext{
${ }^{9}$ Miguéns, Joana, Rodolfo Baggio, and Carlos Costa. "Social media and tourism destinations: Trip Advisor case study." Advances in tourism research 26, no. 28 (2008): pp1-6,1

${ }^{10}$ Carmen Cox, Stephen Burgess, Carmine Sellitto, and Jeremy Buultjens. "The role of user-generated content in tourists' travel planning behavior." Journal of Hospitality Marketing \& Management 18, no. 8 (2009): pp 743-764, 743.

${ }^{11}$ Linn, Marcia. "Technology and science education: Starting points, research programs, and trends." International journal of science education 25, no. 6 (2003): pp727-758, see p 727.

${ }^{12}$ Huotari, Milla, and Eeva Nyberg. "Utilizing social media in a tourism company." (2012). p 62

${ }^{13}$ Gohil, Neeraj. "Role and impact of social media in tourism: a case study on the initiatives of Madhya Pradesh State Tourism." International Journal of Research in Economics and Social Sciences 5, no. 4 (2015):pp 8-15, 9.

${ }^{14}$ Hajli, M. Nick. "A study of the impact of social media on consumers." International Journal of Market Research 56, no. 3 (2014): 387-404, 387
} 
Marketing can be defined as "a social and managerial process by which individuals and groups obtain according to their need and want through creating and exchanging products and value with others". ${ }^{15}$

Marketing is all about understanding the customer or client. Marketing focuses on attracting and delivering value to existing and potential customer in order to ensure satisfaction. ${ }^{16}$ Different elements that effect marketing can be described by five core concepts of marketing as follows:

1. Need, wants and demands

2. Products

3. Value and satisfaction

4. Exchange, transaction and relationship

5. Market $^{17}$

Globally it is an increasing trend of relying on social media as an important tool to communicate and interact with potential tourist. World is evolving on a very fast pace. Traditional communication behavior, marketing, messaging and advertising trends are changing more rapidly than how we tell our story.

By adopting the smart tactics of marketing through social media, organizations are more successful in creating a feeling of trust among their consumers, consequently resulting in an increased sale. ${ }^{18}$

\section{Tourism Companies and Social Media}

Along with all the conventional marketing strategies, social media strategy is a part of almost every tourism company in order to convey the message in such an effective manner to get competitive advantage over other companies. According to "the four pillars theory of social media strategy in marketing "An efficient and successful strategy adopted by the tourist companies comprising;

1. Communication

2. Collaboration

3. Education

4. Entertainment ${ }^{19}$

\footnotetext{
${ }^{15}$ Kotler, Philip, John Bowen, and James C. Makens. Marketing for hospitality and tourism. Prentice Hall, 1996, p. 23

${ }^{16}$ Armstrong, G. \& Kotler, P. Marketing : An Introduction 8/e. Upper Saddle River: Pearson Education Inc.2007, quoted in (Huotari, Milla, and Eeva Nyberg. "Utilizing social media in a tourism company." (2012), p.10

${ }^{17}$ Huotari, Milla, and Eeva Nyberg. "Utilizing social media in a tourism company." (2012), p.10

${ }^{18}$ Safko, Lon. The social media bible: tactics, tools, and strategies for business success. (John Wiley \& Sons, 2010), p.21

${ }^{19}$ Huotari, Milla, and Eeva Nyberg. "Utilizing Social Media in a Tourism Company.” (2012), p.28
} 


\section{Trip planning and the use of social media}

Waxer states that travelers in the recent years are consulting with social media platforms like Facebook, Twitter, You tube, WhatsApp etc. to search for hotels, map their tour routes, critique accommodation and post trip photos. ${ }^{20}$

Conventional methods of arranging a trip are changed after the integration of social media in tourism industry. Social media influence the behavior of traveler from planning and booking the trip and acquiring information to the ways of sharing information and experiences. Social media networking through internet has facilitated by providing the chances of a more facilitated communication and collaboration of users to influence others by sharing and publishing original content like videos, blogs, vlogs, photos and reviews. The original content on social media has the power to influence behavior of traveler. $^{21}$

\section{Tour Related Information and Social Media}

Information shared on social media sites serves as a treasure of knowledge for potential tourists and may can affect their decision making process. The original content shared on social media is more trust worthy, reliable and informative rather than the information shared by any corporate organization. It also fulfills the requirement of tourists by providing them a particular piece of information at a particular stage of their trip. ${ }^{22}$ "Being one of the mega trend that has significantly impacted the tourism system, the role and use of social media in travelers' decision making and in tourism operations and management have been widely discussed in tourism and hospitality research" ${ }^{23}$

\section{Social Media and Consumers' Decision Making Process}

Social media have fundamentally changed the consumer decision process, and in the last decade a more sophisticated view of how consumers engage with brands has emerged. ${ }^{24}$

Modern communication technology either wired or wireless, helps the consumer to generate, transmit and receive information while moving through time and space and

\footnotetext{
${ }^{20}$ Waxer,C. "Tourism boards use social media for broader reach and better targeting . Tourism and social media (online), Available: http://search .proquest.com (Accessed 28 March 2015), quoted in (Madondo, Elvis. "The influence of social media in promoting the tourism industry in Durban, South Africa." Ph.D. dissertation., 2016), p.3

${ }^{21}$ Hays, Stephanie, Stephen John Page, and Dimitrios Buhalis. "Social Media as a Destination Marketing Tool: its use by National Tourism Organisations." Current issues in Tourism 16, no. 3 (2013): 211-239, 211.

${ }^{22}$ Kang, Myunghwa, and Michael A. Schuett. "Determinants of Sharing Travel Experiences in Social

Media." Journal of Travel \& Tourism Marketing 30, no. 1-2 (2013): 93-107, 93.

${ }^{23}$ Leung, Daniel, Rob Law, Hubert Van Hoof, and Dimitrios Buhalis. "Social Media in Tourism and Hospitality: A Literature Review.” Journal of travel \& tourism marketing 30, no. 1-2 (2013): 3-22, 3

${ }^{24}$ Hudson, Simon, and Karen Thal. "The Impact of Social Media on the Consumer Decision Process: Implications for Tourism Marketing." Journal of Travel \& Tourism Marketing 30, no. 1-2 (2013): 156-160, 156.
} 
ultimately succeed in finding a desirable product and services. ${ }^{25}$ It is a two way relationship between social webs and consumers, on one side blogs, vlogs and traveler's ratings are providing a platform for customer's feedback to the tour advisors and potential tourists while on the other side tourism companies and advisors educate the future visitors regarding the products and services they are offering, making them aware of variety of the choices while taking final decision. ${ }^{26}$ There are many sources of inspiration and communication options for a potential tourist and social media users where they can interact, search and share information with other users. A continuous communication between users or potential tourists on social media with online communities, mainstream social media platforms such as Facebook, Twitter and online communities play an instrumental role in helping them either to trust or not in a product or service provider. ${ }^{27}$ The social media platforms are serving as an important source of information for users, so as they come to know regarding any particular destination, hotel, restaurant, brand or a service provider etc., they first check the reviews which make it easier for them to make a final decision about a destination or a service they are interested in. In concluding words Mikalef, Ginnakos and Pateli states, "Social media presents unique characteristics since they allow for user generated content, facilitate synchronous and asynchronous communication between users, and enable immediate content sharing with peers". ${ }^{28}$ Social media has introduced ease for the users to discover new trends, so as compared to print or electronic media, social media has proved more helpful in taking the required information and decision within a short period of time.

Basically decision making is a circular journey involving following steps;

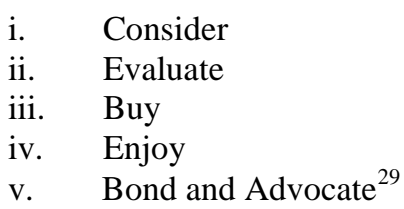

\section{Social media as a source of inspiration for potential tourists}

Social media influences and inspires the public and potential tourists to plan and decide their tour by the motivations explained below:

\footnotetext{
${ }^{25}$ Poster, Mark. "Digitally local communications: Technologies and space." In conference The global and the local in mobile communication: Places, images, people, connections. Budapest.(http://www. locative. snet/tcmreader/index. php. 2004. see P 1.

${ }^{26}$ Ranjha, Ahmed. Promoting tourism in Abu Dhabi using social media. School of Computer Science and Communication, KTH Royal Institute of Technology, 2010. p 21.

${ }^{27}$ Liana, S., "The role of social media in the tourism industry in Austria, How does Austria Implemented the Social Media to Attract Tourists? Bachelor Thesis, (Vienna: Module University Vienna, 2017), p.14

${ }^{28}$ Mikalef, Patrick, Michail Giannakos, and Adamantia Pateli. "Shopping and Word-of-Mouth Intentions on Social Media." Journal of Theoretical and Applied Electronic Commerce Research 8, no. 1 (2013): 17-34, 25. ${ }^{29}$ Court, David, Dave Elzinga, Susan Mulder, and Ole Jørgen Vetvik. "The Consumer Decision Journey." McKinsey Quarterly3, no. 3 (2009): 96-107, quoted in (Madondo, Elvis. "The Influence of Social Media in Promoting the Tourism Industry in Durban, South Africa.” Ph.D. diss., 2016. p.37)
} 


\section{Experiences and Reviews of Visitors}

When travel experiences, reviews and users generated contents are shared on social media, it is considered as most reliable source of information as compared to the information provided by conventional sources of information. The tourism industry is an information intensive industry in which potential tourist need to be exposed to as much information as possible in order to make a best informed decision. ${ }^{30}$

\section{Photo Sharing on Social Media Platforms}

It's a common trend of travelers to share the pictures of personal trip on social media, this online photo sharing has become a norm and social media users easily share, review and respond to photo posted on social media sites. Photo sharing through Facebook and Whatsapp has become more common trend. Reviews of the users on shared photos serves as a valuable source of information about destination for potential tourists. These pictures exhibit the beauty of a tourist spot and attract the users to plan a visit. The photos got likes, shares, reviews and comments thus influencing the decision making process while planning for a trip. ${ }^{31}$

\section{Evaluation of the Alternatives}

"According to Customer Research North America (2015) at the evaluation stage, customer to customer interaction through social media is now playing a pivotal role. In the travel and tourism industry, the research on social media is predominated by blogs and vlogs. These can be most influential tools to reach the potential tourists during the evaluation stage. Tourism companies available online are also influential at this stage". ${ }^{32}$

\section{Research Methodology}

The purpose of this chapter is to explain in detail the research methodology implemented for the study. It was a descriptive study in which quantitative method of research was applied. The population or the target group for data collection was specified to the social media users, while sample of the study were the members of public groups on Whatsapp and the members of tourism groups and pages on Facebook.

As questionnaire is a reliable method of data collection from multiple respondents in an effective and efficient way so online survey questionnaire was used as a tool for primary data collection. The questionnaire was developed and maintained on Google Forms. Twenty three close ended questions with pre-determined answers were utilized in the questionnaire.

The online method of data collection was used. The link of online survey questionnaire was shared on WhatsApp and Facebook. The questionnaire was filled by the members of

\footnotetext{
${ }^{30}$ Madondo, Elvis. "The Influence of Social Media in Promoting the Tourism Industry in Durban, South Africa." Ph.D. diss., 2016, p.30

${ }^{31}$ Ibid., p. 31

${ }^{32}$ Ibid., p. 36
} 
public groups on WhatsApp and members of tourism groups and pages on Facebook. 150 respondents filled the questionnaire. Random sampling technique was applied depending upon the availability and willingness of the members. The data was collected and analyzed on Google Forms automatically.

\section{Findings}

Data was converted into statistical expression automatically on Google Forms in the form of bar-graphs and pie-charts showing percentages of responses to each question. Data collected has been analyzed on the basis of research questions. There were three research questions, the responses has been categorized according to these questions as follows:

\section{Is social media an important source of tourism related information for tourists in}

\section{Pakistan?}

\begin{tabular}{|l|c|c|}
\hline \multicolumn{1}{|c|}{ Questions } & $\mathrm{N}$ & Responses in \% age \\
\hline $\begin{array}{l}\text { Have you ever used social media for travel related } \\
\text { information? }\end{array}$ & 147 & $\begin{array}{c}\text { Yes (78.2\%) } \\
\text { No (21.8\%) }\end{array}$ \\
\hline $\begin{array}{l}\text { Do you use social media platforms to get information } \\
\text { regarding the cost of trip? }\end{array}$ & 149 & Yes (62.4\%) \\
\hline $\begin{array}{l}\text { Do you prefer to use information provided by social } \\
\text { media? }\end{array}$ & 146 & $\begin{array}{c}\text { Yes (79.5\%) } \\
\text { No (20.5\%) }\end{array}$ \\
\hline $\begin{array}{l}\text { Are you ever reluctant to seek travel related information } \\
\text { from social media? }\end{array}$ & 148 & $\begin{array}{l}\text { Yes (51.4\%) } \\
\text { No (48.6\%) }\end{array}$ \\
\hline $\begin{array}{l}\text { Did it ever happened that you have to modify the plan of } \\
\text { your existing trip after getting disappointed from } \\
\text { information obtained by social media platforms? }\end{array}$ & 147 & $\begin{array}{c}\text { No (56.5\%) } \\
\text { Yes (43.5\%) }\end{array}$ \\
\hline $\begin{array}{l}\text { Which one of the following became your favorite tourist } \\
\text { spot after noticing it on social media platforms? }\end{array}$ & 148 & $\begin{array}{l}\text { Northern areas of } \\
\text { Pakistan (71.4\%) } \\
\text { Historical places } \\
(14.2 \%)\end{array}$ \\
\hline
\end{tabular}

- $78.2 \%$ people use social media for travel related information, while $21.8 \%$ respondents do not use social media in this regard.

- Regarding cost of trip $62.4 \%$ people consult social media rather than any other source of information. Remaining $37.6 \%$ people disagree with it.

- $79.5 \%$ people prefer to use information provided by social media while $20.5 \%$ people do not trust social media regarding information.

- Regarding tourism related information $51.4 \%$ users trust social media as a reliable source of information.

- $56.5 \%$ respondents replied that they never felt the need to modify the plan of their existing tour after getting disappointed from the information provided by social media. 
- Northern areas of Pakistan became the most favorite tourist destination of $71.4 \%$ respondents after noticing it on social media platforms.

How does social-media facilitate the tourists in planning their trip?

\begin{tabular}{|l|c|r|}
\hline \multicolumn{1}{|c|}{ Questions } & $\mathrm{N}$ & Responses in \% age \\
\hline $\begin{array}{l}\text { Do you find social media platforms useful for travel } \\
\text { planning? }\end{array}$ & 148 & $\begin{array}{r}\text { Yes (79.7\%) } \\
\text { No (20.3\%) }\end{array}$ \\
\hline $\begin{array}{l}\text { Did social media platforms ever helped you out to } \\
\text { finalize a destination you are intended to visit? }\end{array}$ & 149 & $\begin{array}{r}\text { Yes (73.2\%) } \\
\text { No (26.8\%) }\end{array}$ \\
\hline $\begin{array}{l}\text { Do you think that tourism companies serve a lot to attract } \\
\text { potential tourist towards a particular destination? }\end{array}$ & 148 & $\begin{array}{r}\text { Yes (75\%) } \\
\text { No (25\%) }\end{array}$ \\
\hline Have you ever travelled through any of these companies? & 147 & $\begin{array}{r}\text { No (78.9\%) } \\
\text { Yes (21.1\%) }\end{array}$ \\
\hline If yes than how was your experience with the company? & 134 & $\begin{array}{r}\text { Never } \\
\text { experienced } \\
(70.9 \%)\end{array}$ \\
\hline $\begin{array}{l}\text { Are these companies honest, trustworthy, reliable and } \\
\text { sincere towards their clients? }\end{array}$ & $131.4 \%)$ & $\begin{array}{r}\text { Yes (51.1\%) } \\
\text { No (48.9\%) }\end{array}$ \\
\hline Do you trust tourism companies to plan your future trip? & 145 & $\begin{array}{r}\text { Yes (58.6\%) } \\
\text { No (41.4\%) }\end{array}$ \\
\hline $\begin{array}{l}\text { Do you suggest any social media platform when your } \\
\text { friend needs your suggestion regarding planning of } \\
\text { his/her future tour? }\end{array}$ & 146 & $\begin{array}{r}\text { Yes (71.2\%) } \\
\text { No (28.8\%) }\end{array}$ \\
\hline
\end{tabular}

- In the view of $79.7 \%$ respondents social media is a very useful platform for travel planning, while $20.3 \%$ respondents do not agree with this point of view.

- $73.2 \%$ respondents admitted that social media helped them out to finalize the destination they were intended to visit.

- In the opinion of $75 \%$ respondents the tourism companies serve a lot to attract potential tourists towards a particular destination.

- $78.9 \%$ respondents told that they never travelled through any of these companies, only $21.1 \%$ respondents replied that they have experience of travelling through the tourist companies.

- $51.1 \%$ respondents found the tourism companies reliable, trustworthy and sincere towards their clients.

- $58.6 \%$ respondents replied that they trust the tourism companies to plan their future trip, while $41.1 \%$ people do not trust these companies to plan their future visit. 
- $\quad$ Regarding the planning of future tour $71.2 \%$ respondents suggest their friends to consult with different social media platforms.

How social media platforms are used by travelers to inspire the potential tourists while conducting their trips?

\begin{tabular}{|l|c|l|}
\hline Questions & N & Responses in \% age \\
\hline $\begin{array}{l}\text { Which of the following sources of information } \\
\text { you used last time when you went to a } \\
\text { destination to spend your holidays? }\end{array}$ & 149 & $\begin{array}{l}\text { On my own (37.6\%) } \\
\text { Getting inspired by the } \\
\text { pictures posted by the } \\
\text { tourists (28.2\%) }\end{array}$ \\
\hline $\begin{array}{l}\text { What is the most important factor that helps you } \\
\text { to prioritize your destination? }\end{array}$ & 148 & $\begin{array}{l}\text { Beauty of the place (23.6\%) } \\
\text { Enjoyment (18.2\%) }\end{array}$ \\
\hline $\begin{array}{l}\text { What inspires you most on social media to } \\
\text { finalize your destination? }\end{array}$ & 148 & $\begin{array}{l}\text { Pictures posted by the } \\
\text { tourists (43.2\%) } \\
\text { You tube videos (26.4\%) }\end{array}$ \\
\hline $\begin{array}{l}\text { Do you post your pictures and experiences of } \\
\text { your tour on social media platforms? }\end{array}$ & 146 & $\begin{array}{l}\text { Yes (74\%) } \\
\text { No (26\%) }\end{array}$ \\
\hline $\begin{array}{l}\text { How is the response of your friends and users on } \\
\text { your posts? }\end{array}$ & 143 & $\begin{array}{l}\text { Good (41.3\%) } \\
\text { Very good (25.9\%) } \\
\text { Average (17.5\%) }\end{array}$ \\
\hline
\end{tabular}

- Only 37.6\% people replied that they did not used any source of information about the destination they visited last time rather they decided on their own. While $28.2 \%$ people were inspired by the pictures of tours posted by their friends on social media.

- $23.6 \%$ respondents choose the option that it was the beauty of place that helped them to prioritize the destination.

- $43.2 \%$ respondents were inspired by the pictures of tours posted by their friends on social media.

- $74 \%$ respondents used to post the pictures of their trips on social media platforms.

- Talking about the responses on the posted pictures $41.3 \%$ respondents told that they got good responses while $25.9 \%$ respondents got very good responses.

\section{Discussion and Conclusions}

It is obvious from the results that the trend of using different social media applications has become common, with average customer using at least three social media platforms. The results also demonstrate that the consumers any given application from 21 to 30 days per month. From this we can conclude that interaction with social media is becoming a routine as it aids to satisfy the social, functional and psychological needs of the users. It is seen from results that Whatsapp is the most popular social media app in Pakistan 
followed by Facebook. $68 \%$ users expressed that they are using social media platforms for entertainment and best usage of time. Results show that social media apps are becoming more and more popular day by day as the source of information regarding the planning of the tours. At the same time, it is also noted that the basic reason for consumers using social media for information seeking regarding their future tour is because they have trust in the responses and popular Word Of Mouth of existing and previous travelers. Most of the respondents are interested in visiting those places about whom they came to know and got inspiration from the pictures and views posted by travelers and reviews by their social media friends.

It is seen from results that most of the respondents showed higher level of trust towards the information provided by social media in planning their future tours, which shows that social media is actually contributing in a positive way by providing right and genuine piece of information in the form of posted view and pictures of the destination which inspires the potential tourists to visit the particular destination as beauty of the place is the biggest inspiration to visit a particular place. Northern areas of Pakistan are at the top of the list while talking about the favorite destination spots of Pakistan.

Another strong end of social media concluded from the survey is that social media influences the consumers decision making process, as information is considered more reliable and trustworthy. The travelers use to share their experiences with virtual friends during and after their tour resulting in inspiring more and more users to finalize their future destination.

Concluding from results that traditional advertising was the least famous among the participants and information obtained through social media was ranked higher. Social media is the best communication platform for potential tourists to interact with tourist companies and existing travelers in order to plan their future tour, as most of the respondents showed high level of trust for these companies Either it is the matter of choosing best company with good reputation or a company with economical packages offered for clients, or the matter of cost and availability of hotels and other facilities for tourists, social media platforms not only help in providing direct information but also present a comparison in the form of reviews of travelers and popular Word Of Mouth.

\section{Recommendations}

Pakistan is declared as one of the most potential tourist destinations by different international organizations of the world. The government of Pakistan is expecting a speedy growth of tourism industry of Pakistan within next few years. Beautiful tourist places, historical buildings, ruins of ancient civilizations and remains of ancient religious centers in Pakistan are attracting and motivating not only the domestic tourists but international tourists as well. The present study was confined only to the domestic tourism, so there is a vast scope of carrying out the study from international perspective by analyzing the role of social media in promoting international tourism in Pakistan. Present study might be a little helpful in this regards. 